\title{
欧打による顎顔面骨骨折の様相
}

\author{
本村和彌・山城正宏
}

\section{A clinical and statistical study on maxillofacial fractures from assault and battery}

\author{
Kazuya Motomura - Masahiro Yamashiro
}

\begin{abstract}
Clarifying the features of maxillofacial fractures from a particular cause is very important not only from the therapeutical point of view but also from the aspect of prevention of such fractures; however, no detailed clinical, radiographical or statistical information, except fragmentary, on the maxillofacial fractures from assault and battery seems to be available. Hence we attempted to characterize maxillofacial fractures resulting from assault and battery by clinical, radiographical and statistical observations of 130 such patients with maxillofacial fractures at the oral surgery clinic of the Ryukyu University Hospital during a ten year period from January, 1978 to December, 1987.

In $22.1 \%$ of all the 130 cases investigated, the fractures had resulted from assault and battery with the number of such patients showing a slight increase in recent years. The ratio of males to females was five times greater for males. For both sexes, those in their twenties most frequently sustained such injuries. The greatest number of patients had been injured by fist blows to the maxillofacial regions sustained in street fights after drinking alcohol late at night, occurring slightly more frequently in summer.
\end{abstract}

About one third of the patients were referred to the Ryukyu University Hospital from private dental clinics.

Fractures of the mandible showed a very high rate of occurrence and were seen in 123 cases or $94.6 \%$ of all the maxillofacial fractures. Fracture of the maxilla occurred in 3 cases $(2.3 \%)$ and fracture of the zygomatic in 15 cases $(11.5 \%)$.

In the mandible, $42 \%$ of the fractures (most usual) were seen in the molar and angle area. However, very few fractures were related to the first and second molar. The fracture in the molar and angle area occurred very often in conjunction with the third molar and impaction of the third molar greatly increased the risk of fracture of the mandide. It is suggested that prior extraction of an impacted third molar would reduce the number of maxillofacial fractures sustained in cases of assault and battery.

A total of 264 complications were observed: facial hypaesthesia, 46 cases $(17.5 \%)$; injury of oral mucosa, 46 cases $(16.4 \%)$; fracture of tooth, 38 cases (14.4\%); unconciousness, 33 cases $(12.6 \%)$; injury of facial skin, 28 cases $(10.6 \%)$; infection, 11 cases (4. 2\%); injury of skin or fracture other than facial, 7 cases $(2.7 \%)$ and 5 cases $(1.9 \%)$, respectively; and other miscellaneous symptoms, 52 cases $(19.7 \%)$.

琉球大学医学部晴科口腔外科学教空

(主任：山城正宏教授)

Department of Oral Surgery, School of Medicine,
University of the Ryukyu (Chief: Prof. Masahiro Yamashiro)

受付日: 平成元年 6 月 5 日 
Key words: maxillofacial fracture(顎顔面骨骨折), assault and battery(欧打), clinical, radiographical and statistical study (臨床統計的研究)

緒

言

原因別に颚顔面骨骨折を分類した報告は少なくない が，一定の原因による顎顔面骨骨折の多数症例について 詳細に観察し，検討した研究はきわめて少ない。しか し，ある一定の原因による贔顔面骨骨折について，態栏 や背景などの特徽を明らかにすれは、，臨㕅において利与 るところが大きいばかりでなく，予防に资する諸点が見 い出される可能性がある。

顎顔面骨骨折の原因をみてみる之, 交通事故, 転落・ 転倒, 労働・作業事故、 スホーツなととともに䝘打妇頻 度が高〈1 19), 西原 ${ }^{7}$, 竹之下 ${ }^{8}$, Starkhammar, H. ${ }^{10\rangle}$, Andersson, L. ${ }^{12}$ ，小野 ${ }^{16}$. Perkins, C.S. ${ }^{19}$ らによれば, 䝘打，喧嘩による顎顔面骨骨折の割合は增加している。 しかし，䝘打による顎顔面骨骨折に開与る研究は断片的 であり, 詳細な臨來統計的研究は造㹦し得た限りでは認 められない，そこで今回，われわれは䝘打，喧嘩による 㖽顔面骨骨折の多数例について観察し，その特徵を明ら かにすることを試みた。

\section{調 査 対 象}

調査対象は，昭和53年 1 月から同62年12月31日までの 10年間に，琉球大学保健学部拉よび医学部附属病院歯科 口膑外科を受骖した顎顔面骨骨折患者，全585症例の5
表 1 原因別にみた顎顔面骨骨折の頻度

\begin{tabular}{|c|c|c|}
\hline 原因 & 例 数 & $\%$ \\
\hline 交通事故 & 255 & 43. 6 \\
\hline 㷡打 & 130 & 22.1 \\
\hline 転落・転到 & 96 & 16. 4 \\
\hline スポーツ & 48 & 8.2 \\
\hline 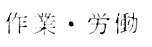 & 34 & 5. 7 \\
\hline 遊龂 & 9 & 1.5 \\
\hline 衡 笑 & 3 & 0.5 \\
\hline その他 & 5 & 1.0 \\
\hline 不 明 & 5 & 1. 0 \\
\hline 計 & 585 & 100 \\
\hline
\end{tabular}

昭和53年 1 月～昭和 62 年12月，琉球大学医学部附属 病院附科口腔外科

ち，殴打によって受賃した 130 例である（表1）。

\section{調 査 結 果}

\section{1. 患者数の年次推移}

最も多く患者が受診したのは昭和 62 年度 (22例), 次 いて61年度（18例），60年度（16例）であり，近年にお ける増加傾向が認められた（図１）。

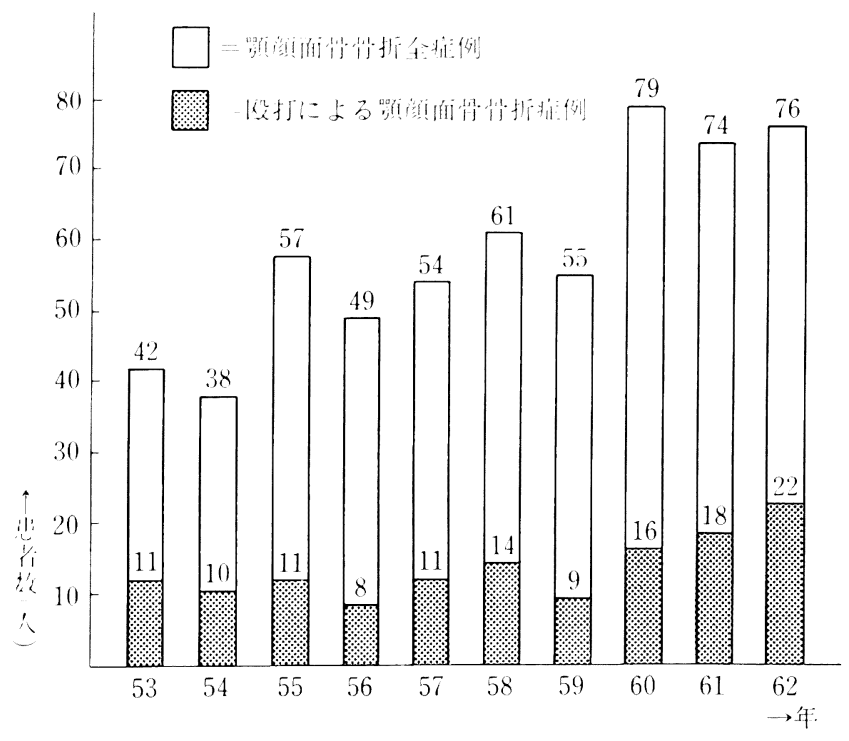

図 1 患者数の年次推移 


\section{2. 年齢, 性別頻度}

10歳代，20歳代，30歳代の若年者が多数で，この年代 の者が全体の $80 \%$ を占めていた，また，男性が女性の約 5 倍で，108人と多数であった（図 2 ）.

\section{3. 受傷月別}

6 月と 8 月, そして 9 月に多く, 夏季に多い傾向がわ ずかに認められた（図了）。

\section{4. 受傷時間}

午後 8 時から, 午後 12 時までの夜間に 40 例と最も多 く, 次いで午前 0 時から午前 4 時までの深夜に37例と多 く認められ，これら時間带に59.2\%が受傷していた（表 2 ).

\section{5. 受傷場所}

場所が判明したのは106例で，そのうち最も多かった のは道路上であった (52例, $49.1 \%)$ ，患者自身の住宅 内で受傷した症例が22例あった（表了）。

\section{6. 作用物体}

四打，喧嘩に用いた物体は106例において確認された が，手拳が最も多く88例（83\%）に認められた（表 4).

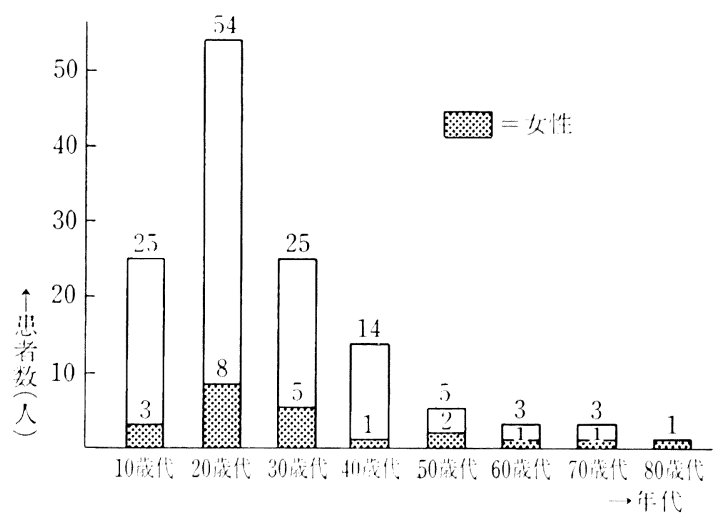

図 2 患者数の年路・性别頻度

\section{7. 受診経路}

病・医院他科が最も多く，60例であった。開業歯科医 院を経て受診した症例は44例 (33.8\%) で，救急診療所 や本院他科を経て受診した症例よりも多かった（表 5).

表 2 受賃時間

\begin{tabular}{|c|c|c|c|}
\hline 時 & 間 & 例 数 & $\%$ \\
\hline 0 & $\sim$ & 37 & 28.5 \\
\hline 4 & $\sim$ & 22 & 16.9 \\
\hline 8 & $\sim$ & 8 & 6.2 \\
\hline 12 & $\sim$ & 7 & 5.4 \\
\hline 16 & $\sim$ & 7 & 5.4 \\
\hline 20 & $\sim$ & 40 & 30.7 \\
\hline & 明 & 9 & 6.9 \\
\hline \multicolumn{2}{|c|}{ 計 } & 130 & 100 \\
\hline
\end{tabular}

表 3 受伤の場所

\begin{tabular}{l|c}
\hline \multicolumn{1}{c|}{ 場 } & 所 \\
\hline 道路上 & 52 \\
自宅 & 22 \\
飲食店 & 11 \\
知人・友人宅 & 5 \\
職 場 & 4 \\
学 校 & 4 \\
公園・広場 & 3 \\
海 岸 & 1 \\
ショッピングンター & 1 \\
エ事現場 & 1 \\
船 舶 & 1 \\
病 院 & 1 \\
\hline \multicolumn{2}{|c}{ 計 } \\
\hline
\end{tabular}

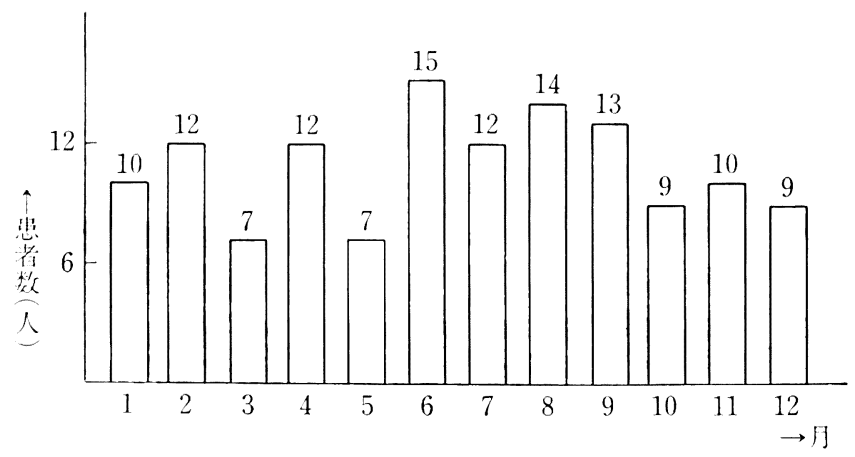

図 3 受符月別患者数 
表 4 作用物体

\begin{tabular}{l|r}
\hline \multicolumn{1}{c|}{ 体 } & 例 数 \\
\hline 手 拳 & 88 \\
足 & 14 \\
角材・棒 & 3 \\
椅子 & 2 \\
木刀 & 1 \\
ハンマー & 1 \\
金属バット & 1 \\
ピールビン & 1 \\
スティック & 1 \\
不明 & 24 \\
計 & 136 \\
\hline
\end{tabular}

表 5 受䛦経路

\begin{tabular}{|c|c|c|}
\hline 医療㙨閶 & 例 数 & $\%$ \\
\hline 病 - 压院他科 & 60 & 46 \\
\hline 開業踭科医院 & 44 & 34 \\
\hline 救急䧐療所 & 17 & 13 \\
\hline 病院街科 & 8 & 6 \\
\hline 本院他科 & 1 & 1 \\
\hline 計 & 130 & 100 \\
\hline
\end{tabular}

表 6 受訬までの時間

\begin{tabular}{c|c|c}
\hline 日 数 & 例 数 & $\%$ \\
\hline 1 日以内 & 41 & 31 \\
$\sim 3$ 日 & 38 & 29 \\
$\sim 7$ 日 & 26 & 20 \\
$\sim 14$ 日 & 10 & 8 \\
$\sim 30$ 日 & 11 & 9 \\
31 日以上 & 4 & 3 \\
\hline 計 & 130 & 100 \\
\hline
\end{tabular}

\section{8. 受診までの時間}

1 日以内に受骖したものが41例と最も多く，次いで 1 日以後 3 日以内が38例であり，80.8\%といら大部分の症 例が 1 週間以内に受骖していた。 2 週間以内に受診した ものは115例 $(88.5 \%)$ である。1 か长きて受診し た症例が 4 例方った（表6）.

\section{9. 飲酒の有無}

調查し得た 122 例についてみると，飲酒の認められた のは81例 $(66.4 \%)$ であった（表 7).

\section{0. 患者の職業}

不明の20例を除いた110例心ついて子ると，最も多か ったのは会社員 (21人) で，次いで土木・建筑策 (17

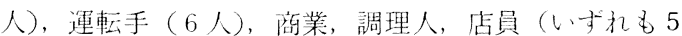
人）などの順であった（表 8 ）.

\section{1. 骨折の様相}

骨折を部位別に分類与ると，下靧骨骨折が 123 例と王

表 8 患者の職業

\begin{tabular}{|c|c|c|}
\hline 職葁 & 例 & 数 \\
\hline 会社員 & 21 & \\
\hline 土木・建筑業 & 17 & \\
\hline 自動車遇転手 & 6 & \\
\hline 商 業 & 5 & \\
\hline 調理人 & 5 & \\
\hline 店 員 & 5 & \\
\hline 监 棠 & 3 & \\
\hline 工 員 & 3 & \\
\hline 澳 業 & 2 & \\
\hline 接客梖 & 2 & \\
\hline 公務員 & 2 & \\
\hline 学 生 & 18 & \\
\hline その他 & 7 & \\
\hline 無 職 & 14 & \\
\hline 計 & 110 & \\
\hline
\end{tabular}

表 7 领酒の状況

\begin{tabular}{|c|c|c|c|c|c|c|c|c|c|c|}
\hline 飲酒 & 年代| & 10藏代 & 20 歳代 & 30 筬代 & 40藏代 & 50歳代 & 60 藏代 & 70臓代 & 80 藏代 & 計 $(\%)$ \\
\hline 有 & $\eta$ & $12(2)$ & $36(4)$ & $16(2)$ & $12(1)$ & $3(1)$ & 1 & 1 & & $81(62.3)$ \\
\hline 無 & L & 11 (1) & $15(3)$ & $7(2)$ & 2 & $2(1)$ & 2 (1) & $2(1)$ & & $41 \quad(31.5)$ \\
\hline 不 & 明 & 2 & $3(1)$ & $2(1)$ & & & & & 1 & $8(6.2)$ \\
\hline 計 & & $25(3)$ & $54(8)$ & $25(5)$ & $14(1)$ & $5(2)$ & $3(1)$ & $3(1)$ & 1 & $130(100)$ \\
\hline
\end{tabular}

（）内は女性の占める例数 


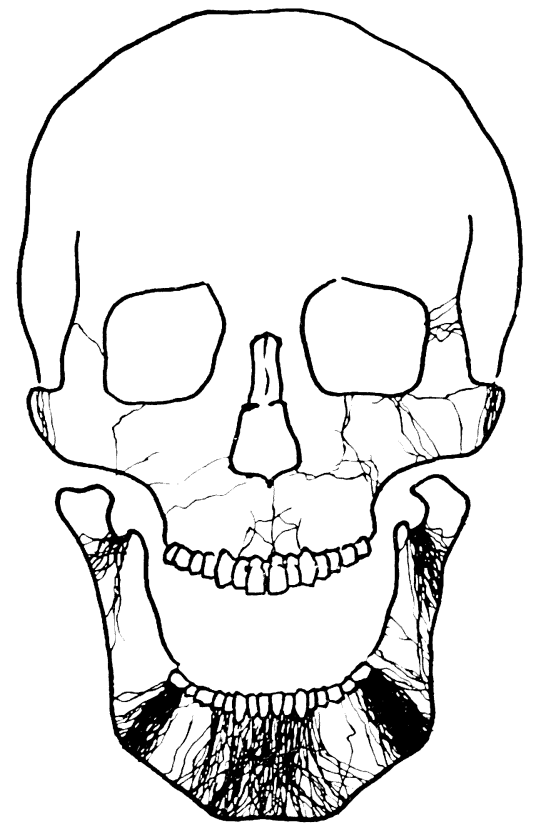

図 4 欧打によ万顎顔面骨骨折 130 例の骨折線

表 9 下顎骨骨折の骨折線による分類

\begin{tabular}{c|c}
\hline & 例数 $(\%)$ \\
\hline 1 線骨折 & $58(47.2)$ \\
2 線骨折 & $55(44.7)$ \\
3 線以上骨折 & $10(8.1)$ \\
\hline 計 & $123(100)$ \\
\hline
\end{tabular}

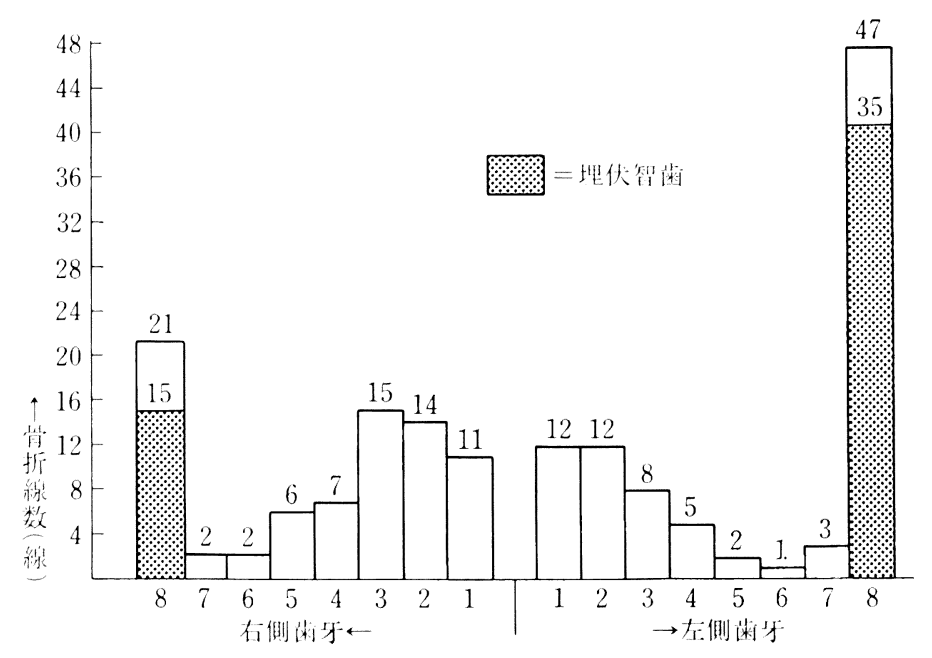

図 6 米種別による下顎骨骨折線の頻度 
表 11 合併症

\begin{tabular}{|c|c|}
\hline & 例数 $(\%)$ \\
\hline 顔面知覚磨盘 & $46(17.5)$ \\
\hline 口腔軟組織損倠 & $43(16.4)$ \\
\hline 噒牙損㑟 & 38 (14.4) \\
\hline 顏面皮成損㑑 & $28(10.6)$ \\
\hline 意識障害 & $33(12.6)$ \\
\hline 他部位皮原損俉 & $7(2.7)$ \\
\hline 他部位悬折 & $5(1.9)$ \\
\hline 感 染 & $11(4.2)$ \\
\hline その他 & $52(19.7)$ \\
\hline 計 & $264(100)$ \\
\hline
\end{tabular}

骨折線と歯牙との関保をみてみると，智歯に関連する 骨折線が最も多く，それは特に左側において顕著であっ た $(47$ 線, $27.9 \%)$, 左右の智米化関連する骨折線は 68 線 $(40.5 \%)$ である。第 1 大曰蔽拈よび第 2 大田歯に関 連する骨折線㹥きわ和少なく，左右で 8 線 $(4.8 \%)$ にすぎ格い，骨折線に関連与る智齿の埋伏の頻度は73.5 \%であった（図6）。

\section{3. 合併症}

顔面知覚麻痺が最も多く，46例 $(35.4 \%)$ 飞認められ た。次いで口腔軟組織損傷が 43 例 $(33.1 \%)$, 歯牙損賃 が38例 $(29.2 \%)$ である。意識障害は33例 $(25.4 \%)$ に 認められ，他に顔面皮侮損賃，感染，他部位の骨折な之 が認められた（表11）。

\section{考察}

上野”は，頡顔面領域の外伤には，顎骨骨折が合併与 ることが多く，その治療には骨片の变位に上り失われた 咬合の回復を主眼とすることが要請されることから、こ こにロ腔外科といら臨床が担らべきひとつの使命がある と指摘するとともに，さらに骨折発生の原因や発生機序 の調査解明から，その予防に役立つ諸点が見い出される ならば,この臨床科学の指向する方向は正しいといえよ うと述べている。その後, 約 25 年が経過した。しかし, 予 防という視点を明確にした顎顔面骨骨折の臨床統計的研 究は、なお少ない。

䫇顔面骨骨折の予防を考方る場合, 特に多発する年代 の患者や原因について調査することは重要である ${ }^{20)}$. 原 因別に症例を分類し，ある一定の原因に上る買顔面骨骨 折の特接を明らかにすれば，臨床において利するところ が大きいばかりでなく，予防に資する諸点が見い出され る可能性がある。そこで今回, われわれは, 㖽顔面骨骨折 の原因として頻度の高い投打に着目, 眨打, 喧嘩による 鿓顔面骨骨折について臨床統計的観察を行い，その実態
や背景を検討した。

炤和53年 1 月から同62年12月までの10年间に，琉球大 学保健学部招上び医学部附属病院歯科口腔外科を受診し た四打による䫇顔面骨骨折患者は130 例て，同年度内に おける顎顔面骨骨折全患者585例の $22.1 \%$ を占めた。こ れは，交通事故 $(43.6 \%)$ に次いで第2 位の頻度になっ ている，四打に上る顎顔面骨骨折の年度別頻度，動向を 調查した報告は少ない. Starkhammar，H．ら は。 ス ポーツや労働事故による症例が増減しないのに較べて, 眨打に上る症例は增加していると指摘し、シートベルト の使用, スピード制限などの交通法則, メルィットの着 用, 学働法なとの安全対策によって䫇顔面骨骨折の危隃 は減少していると考えることは理由があるが，䈋力は顎 顔面骨骨折の原因としてますます重要になってきている ようであると述べている、Andersson，L.ら ${ }^{12} は$ は、キッ クゃ異物, 武器による暴力は今日, 一般的になってお り，長期入院を要する重症例が生じていると注意を喚起 した. Perkins, C.S. ら ${ }^{19}$ は、ンートベルトの法律が制 定される以前は, 顔顔面骨骨折の原因は交通事故が第 1 位であったが，泣律制定後は設打が1位（44\%）であ り，近年，投打に上る罰顔面骨骨折が增加していると述 べている。また, 西原ら れぞれ15年間，17年間，23年間の調查でも経年的な增加

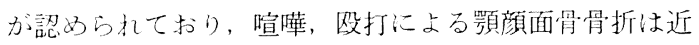
年增加していると考えられる. 今回の, 当科に批るる症 例についての観察結果でも増加が認められた。

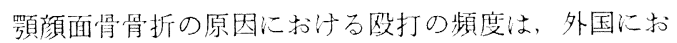
いて高い傾向が少々れる。第2 次世界大戦下, 1944〜 1945年度のインドに求ける下顎骨骨折の原因としての四

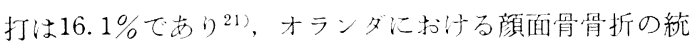
計的観察22では，投打は8\%であるなど低い絬果も又ら れるが, $90 \%{ }^{23)}, 43 \% \%^{5}, 28 \%^{10)}, 45 \%{ }^{12)}, 81.6 \%{ }^{18)}$, $44 \%$ (いずれも第 1 位の頻度) という報告がある。本 邦における頻度は外国のそれより一般にやや低い上らに 思わ机るか，当科比ける殴打の頻度 (22.1\%) は他の 施設比计頻度，12.3\% $\%^{4)}, 17.0 \%, 20.9 \%^{7}, 8 \sim 13.0 \%, 13.9 \%^{9}, 13.2$ $\%{ }^{11)}, 6.5 \%{ }^{15}, \quad 12.3 \sim 18.2 \%{ }^{16)}$ ，などに較べると最も 高い部類に属している。顎顔面骨骨折の原因のありよう が時代の変要を端的に示すことを宫川らはは報告した。

また, Ellis $\mathbb{I I}$, E. $5^{24}$ 法, 地域性, 社会経済状態, 受倁 の年月日, 人口の移動なとによって調查結果は変わると 述べており，社会状況之靧顔面骨骨折は密接な関保があ る。当科括忛る多数の䝘打に上る顎顔面骨骨折の背景 として, 沖縄県民の夜型といわ机る生活様式 ${ }^{25}$, 沖絕戦 後の激動する政治経済情勢を考えることができる．

また，饮酒の問題も無視することができないと考兄ら れるが，本邦に括ける顎顔面骨骨折に関連した领酒例の 報告は少ない(16,26). Lamberg, M.A. ${ }^{5}$ は男性の場合 $59 \%$, 
女性ては $44 \%$ に饮酒が関連したと報告したが，当科にお いて, 饮酒の問題を調查し得な䝘打に上万顎顔面骨骨折 122例についてみると、81 例 $(66.4 \%)$ と多数例に飲酒 が文ら机, 领酒之四打に上万谚顔面骨骨折の密接な関連 性が示された。Perkins，C.S. 5 ${ }^{19)}$ (英) b，四打によ 万罘顔面骨骨折の增加と之もに领酒量も增加しているこ とから, 饮酒量の增加は殴打による㴿顔面骨骨折の增加 と十分開軏するだろらと述べている。飲酒と暴力の関連 性は明らかだけれども，しかし，沖綶県にお忛る酒類の 一世带当たり年間購入額 ${ }^{27}$ は全国最低の部類であること や, Shepherd, J.P. の報告が示すよらに领酒が直接暴 力の原因となるかどうかは疑問である。

患者の年能別, 性别頻度をみると, 若年者の男性に压 倒的に多く，当科に拈计る顎顔面骨骨折全症例について の結果 ${ }^{13)}$ と比較すると, 特に20歳代が突出していた(41.5 \%)。四打による罰顔面骨骨折は，若年者に多発する傾 向がより顕著であるように思われる。

受賃月別をみると，6月と 9 月に多く認められた。月 別の差は僅小であるか，夏季に多い傾向がらかがわれ る.

受榎時閌は午後 8 時〜午前 4 時までの夜間, 深夜が多 かった。これは，上野3果述べているよらに，この時間 帯に飲酒の率が高いことも関倸しているのであろう。調 烃し得た110例についてみると，無職の者は $12.7 \%$ であ った，大部分の症例は日中，仕事に従事寸るために，屋 間には口論や喧嘩から㭱打に至る機会が少ないと考兄ら れる。

受㑺した場所で最も多かったのは道路上であり，次い で自宅, 飲食店, 知人・友人宅, 職場, 学校などの順て あった。これは，戸外の力が比較的自由に行動できるこ とによるのであるら。

作用物作で最も多かったのは手拳てある。上野 ${ }^{3)}$ は, すべて手学で起こっていると述べており， Lamberg， M.A. ${ }^{5}$ は足 (10\%), 鈍器 (6\%) も認められたと報告 した。当科に拈计る症例では手拳のほかに, 足で受倁し た症例が14例 $(10.3 \%)$ 認められ，他に角材・棒, 椅 子、木刀，ハンマーなどさまざまなものが用いられてい、 る.

受診経路で，開業幽科医院を経て受診した症例は 33.8 \%を占めた。これは，当科にお外万顎顔面骨骨折全症 例 ${ }^{13}$ 拉上さ交通技故症例 ${ }^{29}$ の場众 $(28 \%, 6 \%)$ 上り高 い頻度でる。䄪 $1 / 3$ の症例か開業朄科医院を受診して

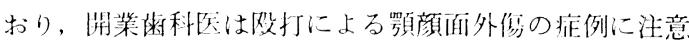
寸べきてあろう。

受骖寺ての時間をみると，60.7\%の症例が受伤後 3 日

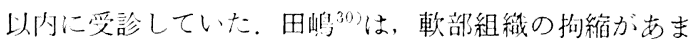
り問题とならない煩骨骨折や買骨骨折なとでは，2週間 前後の待機は特に問題とならないとしている。竹之下

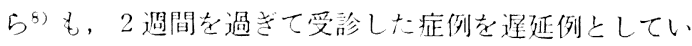

る。今回の調全では， 2 週間以内に受診したものは 88.5 \%であった。1か月を過ぎて受診した症例は 4 例で，そ れぞれ33日，35日，37日，60日を要している。感染によ る腫脹によって受診したものが 2 例，咬合不全，知覚麻 痺を訴えたものが 1 例, 咬筋の萎縮によると思われる咬 合力の低下を主訴として受診した症例が1例であった。

患者の職業は, 学生を除くと会社員が最も多く, 次い で土木建築業, 自動車運転手, 嘀業の順であり,これは 上野 ${ }^{3)}$ の調查と一致していた，営業にあたって利害にか らんだ衝突や飲酒の機会が多いことが関連しているよう に考光られる。

骨折の部位別頻度を钼察すると，下顎骨骨折か压倒的 に多く，今回観察した䝘打に上る顎顔面骨骨折，全 130 症例の $94.1 \%$ にあたる123例に認められた。この割合は， 䫇顔面骨骨折全症例についての钼察結果 $(69.1 \%)^{13)}$ に 比較してかなり高い，䝘打による顎顔面骨骨折は，下㖽 骨骨折が特に多いことが特徵であるように思われる。

下䫇骨骨折の好発部位についてみると, 最も多かった のは大曰蒾および顎角部 (42\%), 次いで前霜部(23\%), 関節突起部 (15\%) などの順である。1,169症例，1,751 本の殴打による下顎骨骨折線の分布について観察した Ellis III，E． ら 24)に上れば，犬歯～第 3 大曰歯部の靧 骨骨体に最も多く $(32.8 \%)$, 次いて䫇角部 $(30.6 \%)$, 関節突起部 $(24.3 \%)$, 前歯部 $(7.1 \%)$ なとの順であ る。大田雨および顎角部骨折の好発傾向が顕著である がこれはひとつには四打による外力が主として大目 雨，罘角部に作用することが多いためではないかと考克 られる。友寄 ${ }^{31}$ は，下顎角部骨折 126 例の原因別頻度

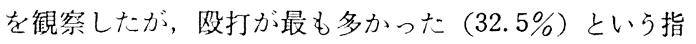
摘も雨者の密接な関係をよく示すものであろう。

下䫇骨骨折線を又ると， 1 線骨折 58 例， 2 線骨折 55 例，3 線以上の骨折は10例である。全症例についての観 察結果 ${ }^{13)}$ と比較すると 1 線骨折が多くなっており， 3 線 以上の複雑骨折は少ない結果であった。片側性の骨折が 過半数の71例 (57.7\%) に認められたが, Khan, A.A. ${ }^{15)}$ も片側性の非複雑性骨折が多かったと述べている。外力 の作用状沉は, 直達骨折 $62 \%$, 介澾骨折 $38 \%$ であり, 全 症例の場合 ${ }^{13}$ に比べて介達骨折が多くなる傾向が認めら れた。

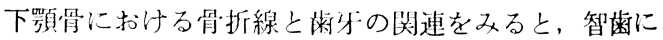
阙連する骨折が最も多く，40.5\%の骨折線が左右の智歯

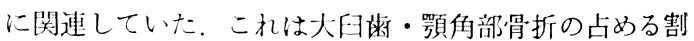
合 $41.8 \%$ にほほ符合している。実際，大兒歯部の骨折と いっても，それはほとんどが智州に関連するものであっ て，第 1 ，第 2 大田嵝汇関連する骨折線はき加めて少な

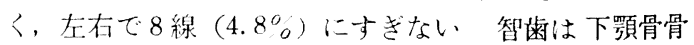
折にきわめて重要な関連を有しているが，その理由とし て同料牙がしばしば埋伏していることがあげられる。下 须骨の禹㑇部は水平枝部が最も薄い部分をもって上行枝 
部に移行しているところであり，あるいは下䫇結合，反 対側のオトガイ孔，下罘骨体に外力が加わった時に応力 変形が生じる場所であって ${ }^{32)}$, 形態的, 力学的に易骨折 部位であるが，智歯の埋伏によって智菌から顎角部，下 䫇下縁までの距離が短くなり,さらに抵抗が減弱して容 易に骨折をひき起こす。小浜 ${ }^{33)}$, 友奇ら ${ }^{31)}$ は, 下顎角部 骨折と智歯および埋伏智歯との密接な関連性について報 告している，今回のわれわれの観察では，下顛骨骨折線 に関連する智歯の埋伏の頻度は73.5\%であった。埋伏智 歯を技去しておくことによって医打による大日歯・頸角 部骨折の多くを予防寸ることが可能であるう。

合併症として最も多かったのは, 顔面皮諙知覚麻瘦 で，35.4\%の症例に認められた。大部分は下歯慒神経の 障害によると思われるもので，下唇からオトガイ部へい たる下顎の皮腐に生じたものである。口腔軟組織損偒, 米牙損傷，顔面皮虎損傷および意識障害は，いずれも䫈 顔面骨骨折全症例の場合 ${ }^{13)}$ に比べて少なくなっている. 意識障害の有無が判明したのは118 例であり, そのらち $27.9 \%$ に意識障害が認められた。時間は全例が 24 時間以 内で，6時間以上の重篤な症例が 3 例あった。時間が不 明であった 23 例の内，15例 $(65.2 \%)$ に飲酒が認められ た，四打による顎顔面骨骨折では，飲酒によって病歴を 十分聴取できないことがしばしばあるので注意しなけれ ばならない。他の合併症として胃骨骨折 1 例, 上肢骨骨 折 2 例, 下肢骨骨折 2 例, 眼結膜充血19例, 複視 2 例, 視力障害 2 例, 鼻出血16例, 聴力障害 1 例, 顎関節脱白 1 例そして腹腔出血による出血性ショックの症例が 1 例 認められた。喧嘩, 䝘打による顎顔面骨骨折症例では, 暴力によって頭部, 眼部, 腹部などに打撲, 外傷を受け ていることが少なくない、時として重篤な合併症が存在 するため, 局所の診査とともに全身的なバイタル・サイ ンのチェックが必要である。

\section{結}

語

一定の原因による顎顔面骨骨折について，態様や背景 なとの特徵を明らかにすれば，臨床において利するとこ ろが大きいばかりでなく, 予防に資する謵点が見い出さ れる可能性がある。今回，当科を受診した殴打による䋶 顔面骨骨折 130 例について検討を加之, 以下の知見を得 た。

1. 昭和 53 年 1 月から同 62 年 12 月 31 日までの 10 年間に 当科を受診した没打による顎顔面骨，骨折症例は130例で， 同10年間における䫁顔面骨骨折全585症例の $22.1 \%$ を占 めた。

2. 患者は，男性が女性の約 5 倍で圧倒的に多く，20 歳代が $41.5 \%$ と突出しており，若年者に多発寸る傾向が より顕著であった。

3. 月別の患者数の差は僅小であるが，夏季に多い傾
向が示され，受傷時間は午後 8 時〜午前 4 時までの夜 間，深夜が多かった。

4. 道路上で最も多く受傷しており，手拳による四打 が最も多かった。

5. 約 $1 / 3$ の症例が開菜菡科医院を経て受骖しており, $88.5 \%$ 症例が 2 週間以内に受診している.

6. 患者の職業は, 学生を除くと会社員が最も多く, 次いで土木建築業, 自動車運転手, 商業の順であった。

7. 下顎骨骨折が特に多く, 下顎骨骨折の好発部位は, 大曰歯・顎角部，前荬部，関節突起部などである。

8. 下顎骨骨折を橉種別に2ると，智歯に関連する骨 折が最も多く，40.5\%の骨折線が左右の智菌に関連して いた。

9. 下擷骨骨折に関連した智歯の埋伏の 頻度は $73.5 \%$ であり，埋伏智䨑を抜去しておくことによって四打によ る顎顔面骨骨折の多くを予防できることが示㖫された。

10. 顔面知覚麻痺, 意識障害, 口腔軟組織損傷, 顔面 皮闻損賃などの合併症が多数みられた。

11）多数例（調查し得た122例中81例， $66.4 \%$ ) に领酒 が認められ，飲酒と四打による頜顔面骨骨折の密接な関 連性が示された。

\section{引用 文 献}

1）宮川喜光，小林八州男，他：顎骨骨折に関する 臨床統計的観察。口病誌 24：87-96 1957.

2) 平川正輝, 池尻茂, 他：我少教公に打忊る擷 骨骨折患者についての統計的钼察。米界展望 16: 910-916 1959.

3）上野正：䫇骨骨折の原因々発生機序。口病誌 31: 115-124 1964 .

4) 川村 七, 橋本 涉, 他：外㑺性顎顔面骨骨折 について(その 1). 臨床統計的観察. 日口外誌 23: 809-818 1977.

5) Lamberg, M.A.: MAXILLO-FACIAL FRACTURES An epidemiological and clinical study on hospitalized patients. Proc Finn Dent Soc 74: suppl 7 11-35 1978.

6）鉿木和彦，三宅久美男，他：過去 12 年間当教室 に打ける頡顔面骨骨折の臨床統計的観察。日口 外誌 24：1084-1090 1978.

7）西原茂昭, 長谷川幸一, 他：過去15年間の当教 宝に扣汁䫇骨骨折の臨床統計的観察。日口外 誌 26: 726-733 1980.

8）竹之下度治，納富一幸，他：䫇骨を中心とする 颜面骨骨折桹相の推䔟。口科誌 31：407-418 1982.

9）乙貫期子, 朝倉昭人, 他：独協医科大学口腔外 科に扣汁る過去 6 年間の䫇骨骨折の臨术統計的 観察。日口外誌 28：127-135 1982.

10) Starkhammar, H. and Olofsson, J.: Facial fractures: A review of 922 cases with special 
reference to incidence and aetiology. Clin Otolaryngol 7: 405-409 1982.

11) 早津良和, 沢本正登, 他: 富山医科薬科大学㳡 科口腔外科に打汁顎骨骨折症例の臨床統計的 钼察。日口外誌 30：126-132 1984.

12) Andersson, L., Hultin, M., et al.: Jaw fractures in the country of Stockholm(1978-1980) ( I ). General survey. Int J Oral Maxillofac Surg 13: 194-199 1984.

13）新崎 章, 山城正宏, 他：顎顔面骨骨折の臨休 的研究一第 2 報: 10 年間の実態と地域的考察一. 日口外誌 32：148-155 1986.

14）津村政則，中務洋一，他：過去11年間当教室に 扣け万顎顔面骨骨折の臨床統計的钼察。日口外 誌 32: 104-108 1986.

15）紀平浩之，田川俊郎，他：過去 24 年間に打ける 当教室の買骨骨折に関す万臨床的睍察。日口外 誌 33：125-130 1987.

16）小野富昭, 和気不二夫, 他：当科に扣ける顎顔 面部骨折に関寸る臨床的検討一第 1 報 臨床統 計的锶察一. 日外誌 34：192-198 1988.

17）任藤田鹤子, 内川裕之, 他：当教窒に打け万過 去 7 年間の顎顔面骨骨折の臨床統計的観察。日 口外誌 34：173-179 1988.

18) Khan, A.A.. A retrospective study of injuries to the maxillofacial skeleton in Harare, Zimbabwe. Br J Oral Maxillofac Surg 26: 435-439 1988.

19) Perkins, C.S., and Layton, S.A.. The aetiology of maxillofacial injuries and the seat belt law. Br J Oral Maxillofac Surg 26: 353-363 1988.

20) 本村和弥, 山城正宏, 他：高校生の顎顔面骨骨 折について一第 1 報：5年間の症例の統計的钼 察一日口外誌 34:675-681 1988.

21) Chambers, I.G. and Scully, C.: Mandibular fractures in India during the second world war (1944 and 1945): Analysis of the snaw- don series. Br J Oral Maxillofac Surg 25: 357-369 1987.

22) Van Hoof, R.F., Merkx, C.A., et al.. The different patterns of fractures of the facial skeleton in four European countries. Int J Oral Maxillofac Surg 6: 3-11 1977.

23) Haynen, A.S.: Statistical report of a series of fractures. Am J Orthod Dentofacial Orthop 25: 478-480 1939.

24) Ellis III, E., Moos, K.F., et al.: Ten years of mandibular fractures: Analysis of 2, 137 cases. Oral Surg Oral Med Oral Pathol 59: 120-129 1985.

25) NHK 放送世諭調查所: 国民生活時間調查県 別編。昭和55年度版, 日本放送出版協会, 東京, 1981，8-9頁.

26) 杉本是孝：嚬骨骨折 45 例の臨床钼察。蔽科学報 68: 842-848 1968.

27）蝓木秀夫，久保幸夫：日本の食生活。初版第 3 刷, 朝食書店, 東京, 1982, 148-149頁.

28) Shepherd, J.P.. Surgical, socio-economic and forensic aspects of assault: A review. $\mathrm{Br} \mathrm{J}$ Oral Maxillofac Surg 27: 89-98 1989.

29）金城秀男, 山城正㕕, 他: 顎顔面骨骨折の臨床 的研究一第 3 報: 交通事故に括忛万統計的観 察—、口科誌 37：904-910 1988.

30）田㣺定夫：顔面骨骨折の治療。第 1 版, 克誠堂 出版, 東京, 1979, 22頁.

31）友寄英基, 久保四郎, 他：下顎角部骨折 126 症 例に関与る臨床的钼察。 日外誌 31 :229022961985.

32) Rowe, N.L. and Williams, J.LI.. Maxillofacial Injuries I. 1 st Ed, Churchill Livingstone Inc, New York, 1985, p 5-6.

33）小浜源郁, 古田 焎, 他：下顎骨骨折317症例 に阅与る臨床的検討，特に骨折線上の蒋牙につ いて。 日外誌 23：45-50 1977. 